\title{
集談会記 事
}

\section{第22回栃木県臨床外科集談会}

昭和 42 年 7 月 15 日

於 栃一県福祉会館

\section{1. 乳幼児そけいヘルニアに対する bilateral exploration について}

済生会宇都宫病院 外科 内山忠塥

乳纳児そけいヘルニアの手術例は年々増加の傾向 亿あり，済生会宇都宮病院でも昭和36年から6 ケ年 間䎲 2 墄以下の症例が 219 例で全症例の $48 \%$ を占め るに至っている。然してれと共に片側へルニア手術 後, 対側ヘルニアの発現は当院の follow up では平 均 $16.2 \% ， 6$ ケ月末淽 $32.3 \%$ 年路ととも減少し てめく傾向がみられた。一方热選択の対側 exploration に上る腹膜鞘状突起の開存率は平均 $49.1 \%$ であ

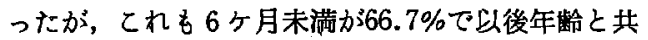
に減少しているが，刘側発現率に比してかなり高率 である。以上のことから腹膜鞘状突起の開存するも のがすべてへルニアに発展するものではなく，自然 閉鎖のあるととが予想される。従って全例の片側へ ルニアに両側手街を行うととは罗当でないが、奶現 発現率が16.2\%あるととから，両侧手術が適応の患 者もいるわけで，今後ての適応の条件を検討してゆ きたい。

2. 当院乳幼児外科の現況について 大田原赤十字病院 外科磯 利次 O前田 勉 鳴田貞博 西堀富士夫 昭和36年より昭和 42 年 5 月に到る間に，当院にお いて外科手術をうけた 6 歳以下の小児の総数は 200

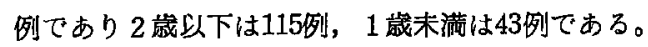
疾患別分類は，先天性外ソケイヘルニヤ157 例, 陰 のう水埂10例, 腸重程13例, 肥厚性幽門狄窄 2 例,

鎖肛 4 例，巨大結腸症 4 例，イレウス 3 例，食道閉 塞症, 胃十二指晹穿孔，先天性結晹狭窄各 1 列外傷 性頭蓋骨份没骨折 4例である。以上の症例について 年度则疾思数, その麻瘦法の種類の変暗についての べ最も多い外ソヶイヘルニヤについて手術時期, そ の処置について若干の考察を行った。また最近 2 ケ 月間につづいて経験した消化管異常の 3 例について 症例報告を行った。

\section{3. 巨大甲状腺腫手術例}

国立杤木病院 外科

○抙江久夫

青木亮一 樋口公明

私達恃，最近，経 $10 \mathrm{~cm}$ 以上の巨大甲状腺腫例を， 何例か経験したので報告する。

症例 181 㒀の女性, 20 年来の tumor で, 最近 次第に大きくなり，頚部圧迫感堌強し，来院㭘查の 結果, 特に異常なく，亜全剔施行，術後経過俚良好 である。

切除 tumor は $15 \times 10 \times 9.5 \mathrm{~cm}$, 重量 $900 \mathrm{gv}$, 病理 検查で follicular adenocarcinoma であった。

症例 2.65歳の女性, 18年前㳙前頸部尰溜江気附 くも手術が，いやで放惪，某医江当科紹介されて来 院, 梌查の結果, 心電図が sinus tachycadia 以外 特に異常なく, 入院手術, 術後, バセドウ様クリー ゼの為, 術後 2 日目に死亡, 病理検査で follicular adenocarcinoma であった。

症例 350 嵅の女性, 15年前より 前顓部 tumor に気附いたが放置, 胙年 6 月, 左鎖骨部の病的骨折 で来院，プローベの結果，甲状腺癌の転移に上るも のと判明, 甲状腺全剔後 ${ }^{191} \mathrm{I}$-Bhg. $80 \mathrm{mci}$ 投与, 知 果があり，経過観察中である。

症例 4 54懇の女性, 数年前より発病, 最近, 急 速に增大, 全剔後, 肺転移で死亡, 病理検查の結果 甲状腺単純癌であっだ。

以上私達は，甲状腺腯の著明なるの，4 例の定例 報告を行ったが，結節性甲状腺腯の手術例は，過去 4 年間，351例で，巨大結節例は，13例，3.6\%であ り, 又巨大例は病脳期間が長く，何れも5 年以上で あり，かかる症例は，殆んどが濾胞系腪演で，且， 覀性が多く，早期治療の必要性を強調した。

\section{4. 頭部外傷に対する開頭術の経験}

上都賀病院 外科 $\mathrm{O}$ 新島昭二 大塚教雄 海老沼光治

吾々は頭部外傷による頭蓋内血廆に対して手術を 行って来たので，その経験を報告した。症例は急性 硬膜外血堹 4 例, 重急性硬膜外血腫, 急性硬膜下血 腫, 覀急性硬膜下血腫夫々 1 例の計 7 例で脳挫傷を 合併した急性硬膜下血厘の1例を除き，他は後遗症 なく治源せしめる事が出来た。

急性硬膜外血瘇は特徽ある意識の推移，眼定状等 
神経学的異常所見が重要な診断の手挂りとされてる が，吾々は定型的症状発現以前に脳血管写により部 断を確定し，時期を失せず開頭術を行って良結果を 得た。経験した 2 歳男子の例では，一見埾症に見え 乍ら大なる血腫を有して居り，小贸の例では特に油 断がならない。亜急性硬膜外血缠及び覀急性硬膜下

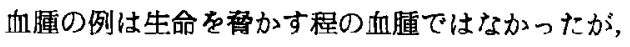
後遗症の袑根を断つ意味で手術は有意義であった。 急性硬膜下血腫は治㙩が甚だ困難であるが血腫を 除去しない限り敕命の可能性がないので, 皘極的に 手術を行うべきものと思う。

5. 空洞切開法が成功したと考えられるじん肺結 核症の二例

珪肺学災病院 外科

○定方正一

それぞれ17年うよび19年 4 ケ月の粉じん歴をもつ 2 列のしん肺結核患者に, 架洞切開療法を施行し た。

1 例は比較的条件に恵まれた症例であったが，1 例は重症なしん肺結核症例で，開放療法は実に 789 日間を必要とした。前者は空洞閉鎖後 7 年 6 ケ月, 後者は 3 年 2 ケ月の現在なお通院中であるが, 病状 は安定し，肺機能の低下も許される範围内にあり， 空洞切開療法が成功したと考えられる。

この 2 症例を吟味してみると，

1）空洞の開放は確かに病状を改善させる。しか し，遺残空洞を開放しないときは充填術は不成功に 終ることがある。その為にも開放療法は直視下で行 ないたい。

2）空洞鿇化の決定を急いではならない。

3）主病单の空洞閉鎖が成功すると，他病单に著 明な改善方期待される。

4）化学療法は空洞閉政後も正しく行なわれると とを还要とする。

6. 瘦著性イレウス再発防止のための腸管内 splinting 法について

済生会宇都宮病院 外科梅園 明 （抄録未着）

7. 食道胃重複啮の一例

足利赤十字病院 外科

星野喜久 田中勝治 渡辺 宽 ○新井健之 村上勝島 伸吾

最近私達は原発性食道胃重複癌の一例を経験した ので，此を報告し，文献的考察を試みた。

患者は69歳男性で主訴は矌下障害で羅病期間は約 2 週間である。心肺機能は著しく低下して居り,る
いそうが著しかった。腫煌は食道の気管分岐部直下 と留底部にあったが，手衍は全身状熊不良の為，第

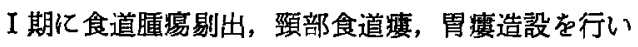

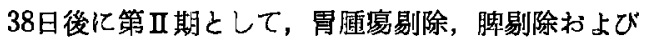
胸喟下食道胃吻合術，幽門形成術，渴瘦造設術を行 った。病理組織学的には食道の腫瘍は角化㑯向を認 めない扁平上皮癌の基底細胞恣で筋層より更に外膜 までおよんでいた。胃の腫湯は papillary-adenocarcinomaで笳層まで曼澗していた。両者間に移行像 を認めず，明らか们同時性多発性原発癌之考えられ る。

重複癌の定義，発生頻度，発生機序および食道青 重複癌の診断，治療等に関して検討を加えた。

\section{8. 当院における早期胃癌集計}

国立杤不病院樋口公明 ○荒井 良
麻族章吾

37 年 4 月より 42 年 6 月まてつ早期胃24例の集計を 行った。性別, 年令别では15：9で男に多く60歳以 上では男に多い。占居部位は中，下部に多く，病巣 の大きは $2 \mathrm{~cm}$ 末满のものが $54 \%$ \%でった。肉腿的に は【、型 5，II型10，Ic+III型 9 例であった。症 状は上腹部痛 $58 \%$ ，膨满，不快感 $54 \% ，$ 体重減少 42 $\%$ ，重圧感，吞酸33\%，悪心，呕吐，食欲不振 $25 \%$ などであった。検查成續は胃液異常73\%，うち無低 酸 $64 \%$ ，過酸30\%，低蛋白血症41\%などであった。 組䅧像は単純癌 6 例, 腺管型腺澏14例, 乳頭状腺痽 3 例であった。深莘度では粘膜内10例，粘膜下14例 であった。リンパ節転移は組織学的に全例陰性であ った。

\section{II. 特別講演}

\section{先天性胆道閉塞症の診断と治嶚}

東北大学教授、葛西森夫

先天性胆道閉塞症の80～90\%は腸と吻合可能な肝 外胆管を欠損し，手術不能例と見做れて居り，所謂 手術可能例も肝機能低下の為に治應例は少く，本症 は小児外科対象疾患のなかでも，最も治療成績の德 い疾忽である。

本症の臨床的特長は生後間すなくより現れる持続 性黄疸と灭白便であり，新生児期より乳児早期に出 現する他の閉害性黄疸との鑑别が問題である。特に 所謂新生児肝炎との鑑别が一番必要であるが，また 最も困難で，凡ゅる肝機能検查はこの目的には殆ん ど無力である。長い期閒の経過観察によれば鑑别は 可能であるが，そのためには先天性胆道閉塞症の手 
術時期を失するととになる。生後 1 2 2 ケで診断 を確定するためには，最終的には開腹術による肝外 胆道の検索が必要であるが，手術前診断としては， 肝の硬さ ${ }^{181}$ I rose-bengal 便中挑泄量の測定, 及び 旰の needle biopsyが 有用である。

肝外胆管が搪張している手術可能型では，消化管 との吻合を行う。技術的には困難でないが, 手術後 の胆汁排泄は必ずしも良好でない。とれは肝機能障 害，肝内胆管内胆泥沈着，胆管上皮の欠損などに基 くものである。所請手術可能型は肝外胆管が欠損又 は痕跡状となっているものであるが，肝外胆管の系 統的探索を行うと，大部分の例に肝閏部で微小胆管 腔を証明する。これらの微小胆管は腸管との正規の 吻合は技術的に不可能であるが，肝門部腸吻合術に よって胆汁を排泄する能力を有し，特に長程 $200 \mathrm{u}$ 以上の内腔を有するものでは早期に手術するととに 上り持続的胆汁排泄を見, 永久治漟が期待出来る。

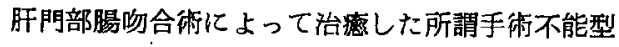
の 5 例の 1〜12年後の検查に上り, 胆汁性肝硬変症 が可成り高度のものでも，䏹汗排泄が可能となれば 数年の経過により殆んど正常の肝組織所見に回復し 得るととを明らかにした。それ故，生後 2 月以内に 旰内部晹吻合術を施行すれば，所謂手術不能型の約 半数は治癔の期待を持ち得るものである。

\section{第 7 回 山口県臨床外科医学会総会 第12回 集談会 山口県労災指定医部会総会}

昭和 42 年 5 月 14 日 於 山口県医師会館

\section{1）特発性総胆管稁腫の 2 例} 山口赤十字病院 外科

田村武男 ○小西目三 高島八郎 高木 輝

最近 1 年間江 2 例の特発性総䏣管䨢腯を経験し た。症例 1 は29歳女性で約 5 年前より䏣石症と診断 されていたが，著しく拡張した総䏣管を認め，特発 性総䏣管変瘇の診断の下, 手術施行, 变腫・十二指 腸吻合術, 脏置的胃切除わよび䏣霞摘除術を行ない 唋快せしぬた。症例 2 は 12 歳女性で生後約 2 年目に 本症と診断され，亦腫・十二指腸吻合術のみを受け ていたが, 約 10 年後, 症状再発し, 吻合部の閉塞を 認めたため，襄偊・空腸物合術抽よび Braun 吻合 を行ない軽快せしめ得た。
以上，特発性総䏣管露隀 2 例を報告し若干の文献 的考察を加えた。

啠問国立下関病院 外科瑇口真㯖雄

1）蒦腯内に結石その他は見られませんでしたか

2）門脈圧六進症状は見られませんでしたか 回答

小西 目三

1）症例2)で前の吻合部と思われる部䎲綿くづ様の 液死組織らしきもの十数個を認めた。結石はな 加た。

2)瑟めませんでした。

\section{2）先天性食道閉鎖症手術例の反省}

山口赤十字病院

外科 田村武男 小西目三 高島八郎 O高木 輝

小児科 門屋昭一郎 田崎 考

我々は生後 4 日目に来院した Gross のC型の先 天性食道閉鎖应に対し，右開胸にて食道気管壖閉鎖 及び食道端々吻合術（一層檤合）を施行したが，術 後32日目に肺炎で死亡した。思児の剖梌により Rehbein のいう二重瘦であった事を知った。術中，検 索不十分であったため不幸の転機をとったととを反 省し加えて若干気づいた点をあわせ報告した。

追加, 質問 国立下関病院 外科 湰口真意雄 1）胃㾇の適否，時期については現在画一的結論は 出ていない，しかし私見として胃液が食道気管瘦を 通じて逆流，または肺内ガスが胃に流入し呼吸抑制 をおてす等，要循㻴を来たすので要すれば設置した がよい。

2)経畺カテーテルの適否についてもGross 等は 反対しており，種々の欠点あり。手術手技を容易に するためにはよいが，その後は胃㾇設置のみがよい 3）上部食道と下部食道の口径がかなり異なります が下部食道の口往拡大法はされませんでしたか

回答 山口赤十字病院 外科田村武男

本症は Lehbein のいう二重瘦で先天性食道䦥鎖 症 265 例中 5 例という稀有な奇型であってとれが死 因である。

胃燸は設置したがよいが，経験上なくてやれるも のならつくらない方がよい。

3）気脱術が劇的奻果を示したジャクンン型演痛 重積症の 1 例

宇部興産中央病院 脳神経外科洨辺浩策 高島正成

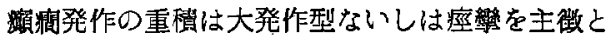
するものにしばしば見られるが，稀には小発作やミ 
オクローヌスの重積も見られる專がある。

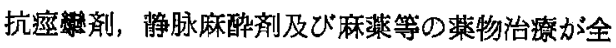
く無效で，痤踌の重稍が13日間持続したジャクソン

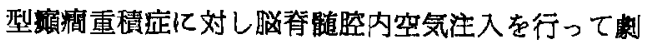
的度消失せしめた 1 症例を報告した。

追加山口労炎病院 石田一夫

気脳写により逆にてんかん（重䅡）発作を 1 回だ け誘発 1 例を追加した。しかし本症に気䁘写を試み てよくないとは思っていない。

4）热椎骨折及び脊领損俉に対する観血的整復固 定の小経験

南陽病院 整形外科北男

plate 及び bolte による春椎固定㫦を経験したの

で報告する。

店例 120 墄男子，交通事故にて第 1 腰椎前方脱 日，第 2 腰椎圧迫骨折で両下肢の知覚，運動麻脌を きたし, 受傷後18日, 部分的椎马切除術とともに施

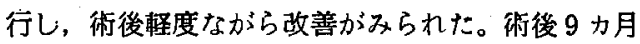

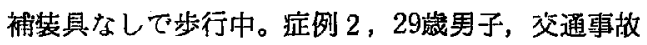
にて第12胸椎前方脱臼，第 1 腰椎圧迫骨折で両下肢 の知覚・運動麻㿉をきたし，受愎後 5 日，部分的椎 弓切除術と已もに施行。術後著明に改善され，而下 肢の自動運動は可能となる。症例 3 30才, 男子。 4 米高より落ち第 1 腰椎压迫骨折の非麻㾝例で, 受 傷後12日整復固定術を施行し経過良好である。脊椎 骨折及び脊髄損傷に部分的椎弓切除衡及び宜椎整復 固定術の可否に関して若干の文献的考案を加えた。 僅少で短期間のため今後更に症例をかさね, Böhler 法による保存的治療成績と此較検討してみたいと思 50

5）前立腺癌の骨（助骨）転移の1例

国立療荃所 山陽荘 八塚陽一森重照夫 3 年前に前立腺癌の手術を受け，最近肺野に異常 陰影を発見され，手術の結果，それが肺内のものて なく，癌の肋骨転移であると判明した 1 列を経験し

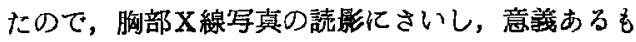
のと思い報告する。

質問 山口大 第 2 外科青木秀夫

1）転移盾瘦は何番目の胁骨に䎑められたのか。

2）相当大きな腫留ですが，第 6 助骨の上下の肋骨 の変化はいかがでしたか

6）再発末期乳密に対する副腎静脈，結腸静脈吻 合衍の検討

国立下関病院 外科

䓓口真喜雄
我々は再発末期乳癌㭧者 2 例々対し両側卵巣摘出 右副婜摘出, 左副腎静脈, 結腸静脈沟合術を行っ た。第一例は66歳の女。昭和33年1工月左乳癌根治術 以来，合計11回の局所再発癌切除を受けて居り主新 は左鎖骨上部より鎖骨下方胸内觔膜に及心゙る全く移 動性なき硬固な婳痬と麀側上肢の腫脹疼痛であった ため切除不能と考え上記手術を施行。とれにより en block dissection も可能となり上肢の腫脹, 炵 痛, 垃減し样快退院。第 2 例注59歳の女。昭和38年 4 月右乳癌根治術施行後 41 年 4 月右前胸䇒再発癌を きたし下部肋骨及び肋膜に浸潤し，全く移動性なく 切除不能と考元上記手術と M.M.C. 併用療法老行い 局所再発癌部の萎縮，缸死をきたし切除可能となり 样快退院したが，その後，左肺及び肝転移をきたし 死亡。尚，吻合結腸静脈注中結腸静脈分枝を利用 し井口式血営吻合器を伐用した。本手術法の自他覚 症状の改善率は $50 \%$ 上考えられろ。尚，種々文献的 考察を試みた。

7）腹壁ヘルニアに対する Teflon-mesh 使用 治殹例

山口大 第 2 外科 田中忠良 山時好郎

我々は最近巨大腹垶癞痕へルニア 2 症例に対して 補埧補強材として合成線維網，Teflon-mesh を用い 良好な結果を得た。

Teflon-mesh 補填部の翼物感，異和感の訴え 6 な く腹圧による膨隆も绻められなかった。術後約 1 ケ 月を経て，Teflon-mesh 綎着部の感染系の遊出を来 たしたが, Tefion-mesh の遊離は認められず Ludig ton の提唱する，理想的補填補強材としての12項目 の条件をほぼ完全に满しており，Teflon-meshが優 秀な補埧補倠材であるととを認めるものである。

しかし症例 1 亿述べた様に腹膜欠換を伴う場合， 腸管の強度藻着を認めた。橋本氏も腹膜欠換を伴う 症列では大多数认術後，渴管或は大網の慗着を認め ている。この着着現象は柽視出来ない問題であり， Ludington の12項目に加えて13項として虑着現象の ないこと，の1項目を追加したいるのである。平氏 は Teflon-mesh-Gelatin-sponge を使用し痖着防止 に良好な結果を得ているが，我々も今後充分検討す バき問題であると考える。

追加 山口大 第 2 外科 青木秀夫 1) テフロンメッシュはメリヤス編になっているか ら編目が直角に交差するよう二重にして使用した。 2）筋膜と檤着する場合にメッシュの断端を折返し てわいて积着させた方がよいと思われる。 
追加 都志見病院

都志見善視

そけい巨大へルニヤにもテフロン補強の適応があ る事を附言した。

追加, 質問 国立下関病院 外科 溝口真喜雄 1) Teflon-Mesh 使用, 腹壁へルニア手術は保険採 用になっていますか。

2）我々は41歳の女子, 虫垂炎術後腹壁へルニアの 根治手術を他病院で 4 回うけているがいづれも失 敗。我々のところで本例にパイレンネットを使用し 異物反応なく順調に経過した 1 例を経験。価格が安 く組織反応殆んどなく手技も簡単な利点等あり。

8）最近経験した早期癌並に小胃癌について 萩市 都志見病院、都志見善漞 ○原口幸昭 最上 栄蔵 古賀 禧子

\section{9）特異な経過を示した Afferent Loop Syn-} drome の 1 例

南陽病院 外科 ○岡谷照太 吉岡 章 Billroth II 胃切除術後に発生する輸入脚部関す る troubles は, 此較的稀なものであるが，我々は 最近約10年前に胃切除をうけ，その後順調に経過し ていたに拘らず,急激に発生した Afferent loop obstructin の1例を経験したので, 若干の文献的考察 を加え，今日すでに極めて一般化している手術手技 に関しても，なお再検討を要するととを述べ，てれ ら iatrogenic disease の発生の防止に弩めるべきで あるととを強調した。

\section{0) Afferent Loop Syndrome について}

山口学災病院 外科石田一夫 森田渉森山正明 われわれは, 胃切除術を行うに際して, B-I法, ，Ｉ法を，また川法で前結腸吻合の場合には，通常 ブラウン㽡合を行うととにしている。最近川法で, 前結腸吻合を行ない，ブラウン吻合を設置せず，輸 入脚のつりあげを 3 針行なったものが数例ある。こ の数例のうちの一例がたまたま輸入脚症候群を発生 したが，幸いにブラウン吻合の追加で，全治せしめ たので，てれを報告し，ての䦗題について，若干， 文献的考察を試みた。

\section{追加質問都志見病院都志見善親}

afferent loop syndrome 防止上, 後部式が良いと 思う。
追加質問 国立下関病院 外科、㴖口真喜雄 1）血清ヂアスターゼ值は術前上昇していませんで したか。かかる症例はファーター氏乳頭部の二次的 浮腫による急性膵炎の合併が見られることがあるの ですが。

2）本症例は最近增加の傾向にあり診断の遅速は予 後影響重大である。

3）我々のところでてれの防止対策として

(1) afferent loop は長くとらないとと

(2) 輸入脚 suspension を食道下部近くの横隔膜 そまで固定する。

(3) 輸入脚を岸入しないように適当なところで数 針固定する。

追加都志見病院 外科古賀 禧子 最近胃切除例数の増加に伴い切除後の愁訴に対す る種々の対策が講じられている。我々は胃癌或は老 年者に対しては原則としてBＩ法をおてなっている が, 幸いにも輸入脚症候群等のひどい術後障碍のあ るものを経験していない。私共は胃潰痬ないしは早 期胃癌例に対してはより生理的なB I 法を行なって おり，最近ではととに胃内停滞時間延長のために独

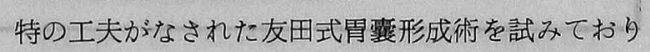
現在までに12例を経験している。術後経過は日が浅 いきらいはあるが，いづれも術後愁訴が少なく良好 な結果を得ている。

その1例を示すとスライドのでとくで十分な胃内 停滞を認める。以上我々の経験した胃囊形成術につ いて追加した。

\section{特別講演}

乳癌根治手術 山口大 教授 八牧力雄 腹部外科と精神身体医学について

九大 心療内科講師 中目也 初期乳癌（乳腺症を含む）の診断と治療

九大教授 年口 潔

\section{学術映画}

頭部外傷東大 脳神経科教授 佐野圭司 血管吻合術式 九大 教授 井口 潔 